\title{
Halysis Høeg, 1932 - an ancestral tabulate coral from the Ordos Basin, North China
}

\author{
Li-Jing Zheng ${ }^{1,2,3}$, Hong-Xia Jiang ${ }^{4^{*}}$ (D, Ya-Sheng Wu ${ }^{1,2,5}$, Hong-Ping Bao ${ }^{6}$, Yue-Yang Zhang ${ }^{1,2,5}$, Jun-Feng Ren ${ }^{6}$ and \\ Zheng-Liang Huang ${ }^{6}$
}

\begin{abstract}
The problematic calcareous microfossil Halysis is abundant in the Middle Ordovician Darriwilian Stage of the western edge of the Ordos Basin, North China. The rich and well-preserved specimens of Halysis in this area facilitate detailed studies for its skeletal construction and tube microstructure. Halysis differs from calcified cyanobacteria and calcareous red and green algae in morphology, skeletal construction and microstructure, as well as reproduction mode. Halysis typically consists of multiple juxtaposed parallel tubes arranged in sheets ('multipletube' type) or is just composed of one tube ('single-tube' type). In 'multiple-tube' Halysis, tube fission by bifurcation results from the insertion of a microcrystalline wall at the center of a mother tube. This study demonstrates for the first time that the tube walls of Halysis have a laminofibrous (fibronormal) microstructure, composed of fibrous calcite perpendicular to wall surface, and recognizes the 'single-tube' type Halysis composed of one tube; in addition, for the first time, this study finds out that 'multiple-tube' Halysis develops buddings from the conjunction of two tubes and 'single-tube' Halysis shows wide-angle Y-shaped branchings. Based on these findings, this study further compares Halysis with tabulate corals. Halysis appears stratigraphically earlier than Catenipora and Aulopora, and has a smaller tube size. 'Multiple-tube' Halysis resembles Catenipora and 'single-tube' Halysis resembles Aulopora in skeletal construction and microstructure, and in their tube walls of laminofibrous microstructure composed of fibrous calcite perpendicular to the tube wall surface. Catenipora and Halysis are both characterized by the absence of septal spines. The similarities suggest that Halysis may be the ancestor of Catenipora-like and Aulopora-like tabulate corals.
\end{abstract}

Keywords: Halysis, Morphology, Taxonomic affinity, Middle Ordovician, Tabulate coral, Wuhai, Inner Mongolia

\section{Introduction}

Halysis Høeg 1932 is a problematic calcareous microfossil occurring commonly in Early- to Mid-Paleozoic carbonate rocks (Shen and Neuweiler 2015). It has been reported from shallow marine limestones of the Lower Ordovician to Devonian Systems (Guilbault et al. 1976; Poncet 1986; Mamet and Shalaby 1995; Munnecke et al. 2001; Riding and Braga 2005; Feng et al. 2010). Halysis was originally described as a chain of spherical cells by Høeg (1932). Others considered it to be composed of a

\footnotetext{
* Correspondence: jianghx@mail.iggcas.ac.cn

${ }^{4}$ Institute of Paleontology, Hebei Geo University, Shijiazhuang 050031, Hebei Province, China

Full list of author information is available at the end of the article
}

row of tubes (e.g., Guilbault et al. 1976). Riding and Braga (2005) interpreted the tubes in Halysis as laterally adjoining cells. Some researchers (Munnecke et al. 1999, 2001; Frisch et al. 2013) disagreed with the interpretation of a row of parallel tubes or cells and interpreted Halysis as consisting of parallel-juxtaposed, partlybranching tubes. Shen and Neuweiler (2015) confirmed the palisade-like arrangement of tubes in Halysis. In this study, we present evidence that some Halysis samples are composed of single tubes and have 'single-tube' skeletal construction.

With regard to the affinity of Halysis, Munnecke et al. (1999, 2001) considered that the skeletal ultrastructure of Halysis strongly resembles those of cyanobacteria,

\section{Springer Open}

(c) The Author(s). 2020 Open Access This article is licensed under a Creative Commons Attribution 4.0 International License, which permits use, sharing, adaptation, distribution and reproduction in any medium or format, as long as you give appropriate credit to the original author(s) and the source, provide a link to the Creative Commons licence, and indicate if changes were made. The images or other third party material in this article are included in the article's Creative Commons licence, unless indicated otherwise in a credit line to the material. If material is not included in the article's Creative Commons licence and your intended use is not permitted by statutory regulation or exceeds the permitted use, you will need to obtain permission directly from the copyright holder. To view a copy of this licence, visit http://creativecommons.org/licenses/by/4.0/. 
e.g., Girvanella, and proposed that Halysis is a morphologically highly variable, palisade-like cyanobacterium. Riding and Braga (2005), however, compared Halysis with coralline-like red algae in cell size, cell shape, wall structure and flattening. More recently, Shen and Neuweiler (2015) interpreted Halysis as a siphonous green algae, citing similarities in skeletal architecture, growth form and biostratinomy. Although Halysis has been studied for nearly one hundred years, its systematic position remains in dispute.

Halysis occurs abundantly in a deepening-upward succession of Darriwilian-age limestones in the Ordos Basin, North China. It is present in both the underlying shallow water bioclastic calcarenites and the overlying thin-bedded deeper water marls. It has potential as an indicator of the sedimentary environment. Based on an examination of two hundred thin sections during this study, we found that (1) Halysis specimens from the Ordos Basin have a wall microstructure similar to those of tabulate corals, but different from those of cyanobacteria, coralline red algae and green algae; (2) many specimens of Halysis are composed of a single tube. Also we studied the mode of branching and tube fission for clues to Halysis' affinities.

\section{Geological setting}

The studied section is geographically located on the Laoshidan Mountain of the northwestern Ordos Basin, southeast of the Hainan district in Wuhai City, Inner Mongolia Autonomous Region, North China (Fig. 1).
Lower and Middle Ordovician strata are widely exposed in the Hainan area; the Upper Ordovician series is also present, but generally has been eroded away (Wang et al. 2016; Zheng et al. 2018). The Ordovician strata in this area are divided into seven formations: Sandaokan Formation, Zhuozishan Formation, Kelimoli Formation, Wulalike Formation, Lashizhong Formation, Gongwusu Formation, and Sheshan Formation (Jing et al. 2015), from base to top. A succession of the Middle Ordovician Zhuozishan and Kelimoli Formations is the focus of this study. The succession is more than $600 \mathrm{~m}$ thick and consists of calcarenite, marlstone, dolomitic limestone, dolostone, limestone and shale (Fig. 2).

Halysis occurs in the $184.7 \mathrm{~m}$ to $304.9 \mathrm{~m}$ interval of the studied section, with associated fossils including cyanobacteria (Girvanella), gastropods, brachiopods, cephalopods, echinoderms, trilobites, and the calcified cyanobacterium Fontofilia furculata Wu et Liu, 2015 (Yang et al. 2015) (Figs. 2 and 3). The presence of the conodont Histiodella kristinae in this interval, which has also been recorded in western Newfoundland (Stouge 1984; 2012) and the Tarim Basin (Stouge et al. 2011), indicates a middle Darriwilian age (Wang et al. 2013; Jing et al. 2015; 2016).

\section{Material and methods}

The Middle Ordovician Zhuozishan and Kelimoli Formations of the Laoshidan section were mainly composed of carbonate rocks of a variety of sedimentary facies, and were measured meter by meter (Fig. 2) in this study. A total of 267 hand specimens were collected at an interval

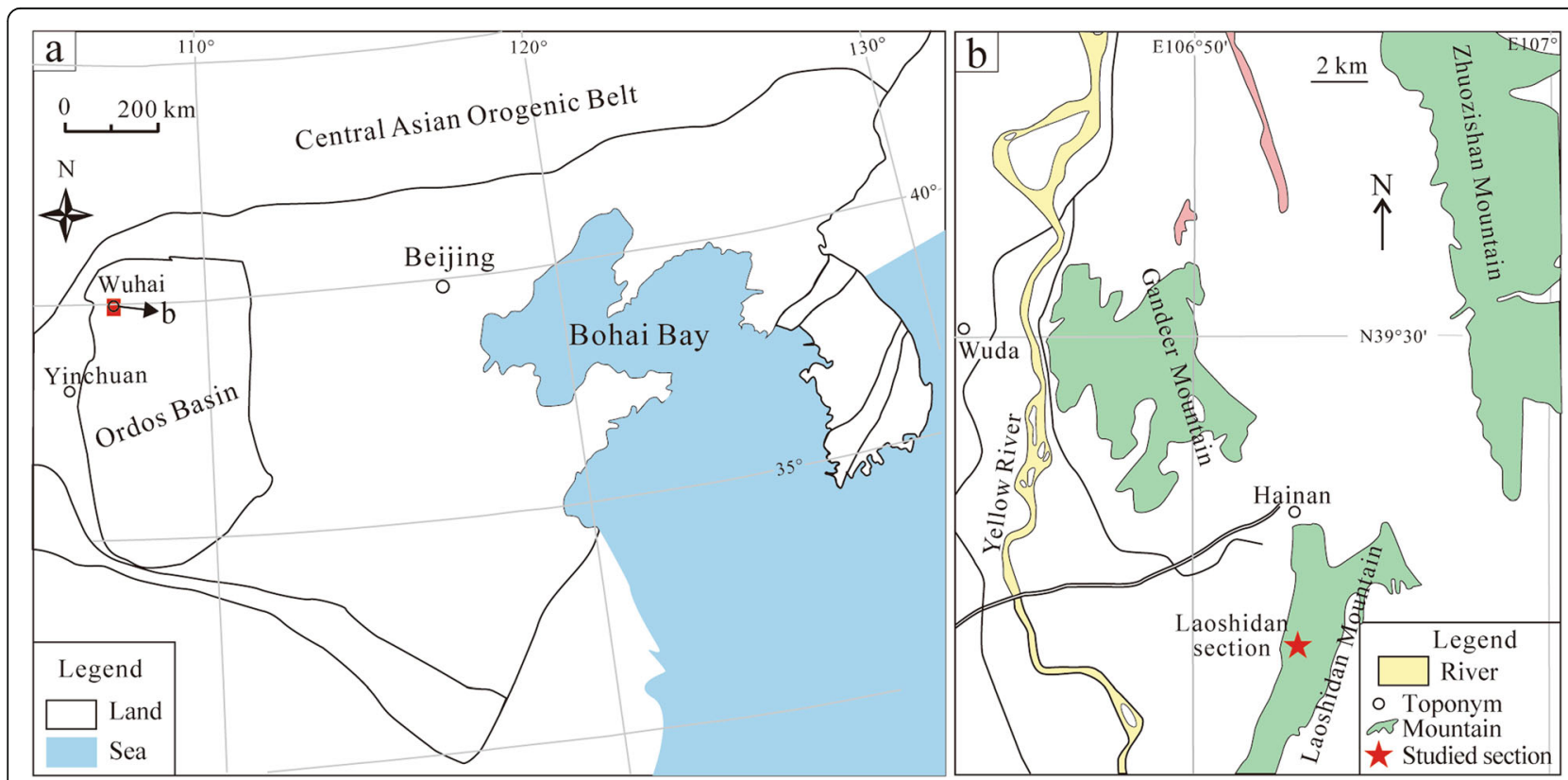

Fig. 1 a Schematic map of the study area (red rectangle), located in the northwest of the Ordos Basin, North China (modified after Zhu et al. 2012); b Location of the Middle Ordovician Laoshidan section (red star) (modified after Jing et al. 2016) 


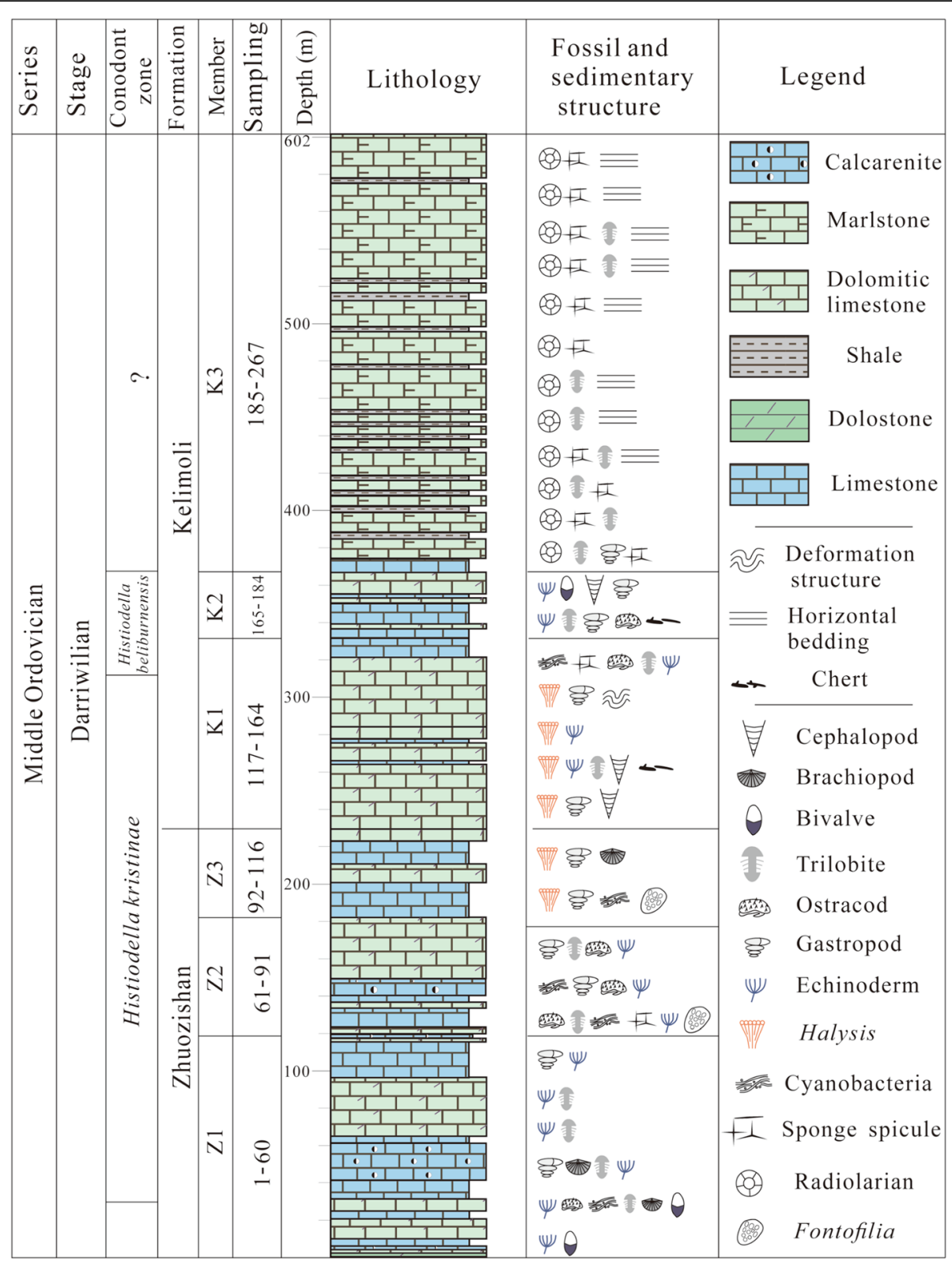

Fig. 2 Lithostratigraphy and main fossils of the Middle Ordovician Laoshidan section, Northwest Ordos Basin, North China. The conodont zonation is from Jing et al. (2016)

by two or three meters, and 267 thin sections were made from these samples. Examination of thin sections revealed the presence of Halysis in 24 thin sections from the upper Zhuozishan Formation to the lower Kelimoli Formation (Fig. 2; Members Z3 and K1), particularly from the Member Z3. In addition, we examined 6 thin sections with Halysis from the Upper Ordovician Lianglitage Formation of Bachu area in the Tarim Basin (Cai et al. 2008). Lithological and paleontological features of the thin sections were examined using an Olympus BX 41 transmitted light microscopy, and thousands of photomicrographs were taken. The microstructure of
Halysis was observed by Olympus BX 41 transmitted light microscopy and by FEI Quanta 450FEG scanning electron microscopy (SEM) at the PetroChina Research Institute of Petroleum Exploration and Development. The Halysis samples were coated with gold and observed under the SEM at $5 \mathrm{kV}, 0.4 \mathrm{~mA}$. Morphometric analysis of Halysis was performed following the methodology of Munnecke et al. (2001), Frisch et al. (2013) and Shen and Neuweiler (2015).

Comparisons of Halysis with calcareous cyanobacteria (Girvanella), algae (Dasycladales, Permocalculus, Pseudosolenopora filiformis), and tabulate corals (Catenipora 


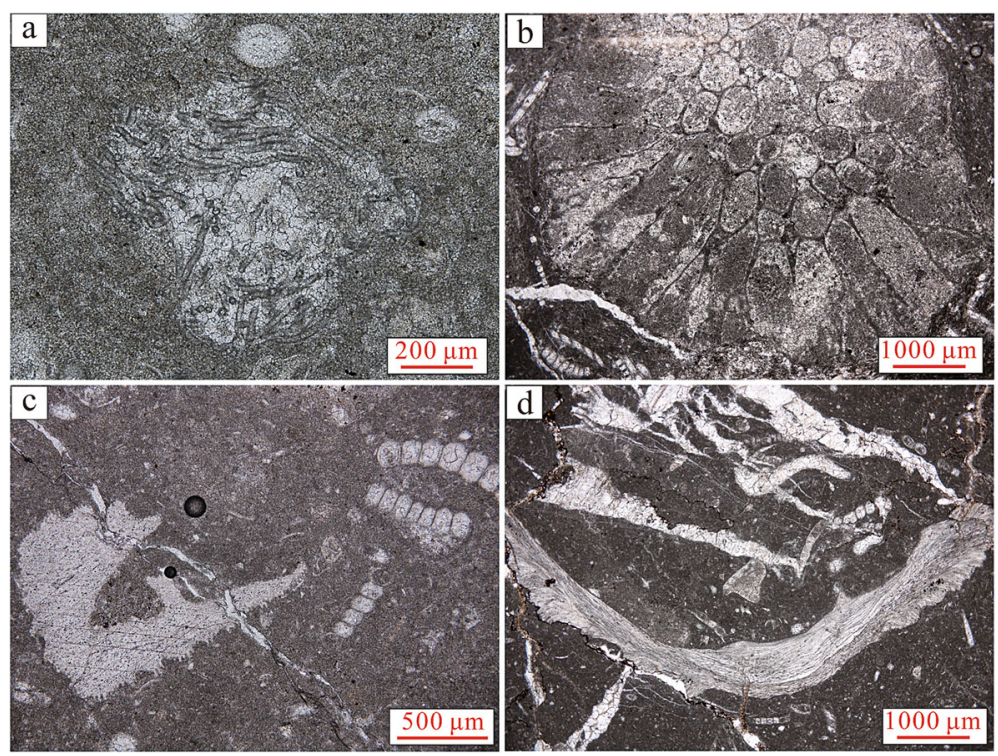

Fig. 3 Photomicrographs showing organisms associated with Halysis from the Laoshidan section, under transmitted light. a Girvanella; b Fontofilia furculata Wu et Liu, 2015; c Crinoid; d Brachiopod

and Aulopora) were made based on their skeletal microstructure, tube size and mode of reproduction. Dasycladales and Girvanella specimens from the Ordovician of the Ordos Basin, Permocalculus from the Middle Permian of the Lengwu section (in Zhejiang Province), Pseudosolenopora filiformis from the Upper Ordovician of the Tarim Basin, Catenipora from the Upper Ordovician Sanqushan Formation of Yushan area (in Jiangxi Province) were studied, and, Aulopora from the Lower Devonian Sipai Formation of Xiangzhou area (in Guangxi Province) were compared. Where the Halysis tubes are arranged in sheets and present a chain- or bead-like appearance in transverse section, we use ' $\mathrm{Dp}$ ' to signify the diameter of tubes measured parallel to the alignment of chains, and 'Dn' for the diameter of tubes measured normal to their alignment of chains. 'Wp' signifies the wall thickness measured parallel to the chain alignment, and ' $\mathrm{Wn}$ ' is the wall thickness measured normal to the chains.

\section{Results}

\subsection{Morphology of Halysis}

In this study, Halysis occurs in thin- to medium-bedded dolomitic limestone and limestone of the upper Zhuozishan Formation and the lower Kelimoli Formation (Z3-K1; Figs. 2 and 4a). In some horizons of the Zhuozishan Formation, it forms the principal grain component of wackestone and packstone (Fig. 4b-d).

In most cases, Halysis consists of multiple juxtaposed parallel tubes arranged in sheets (Fig. $4 \mathrm{~b}, \mathrm{~d}$ ), and then is termed 'multiple-tube' Halysis, in which the number of tubes ranges from 2 to more than 30. Less commonly,
Halysis is just composed of one tube (Fig. 4c, d), and termed 'single-tube' Halysis. In longitudinal sections, tubes of both types can be of very variable length. The tubes in 'multiple-tube' Halysis are parallel to each other (Fig. 4e), and juxtaposed, forming a palisade-like structure. Most tubes are relatively straight to gently curved but occasionally show bending (Fig. 4f). In cross sections, Halysis tubes range from circular to elliptical and even square (Fig. $4 \mathrm{~g}, \mathrm{~h}$ ). The infilling of the tubes is typically sparry calcitic (arrow in Fig. $4 \mathrm{~g}$ ) but can also be micritic (Fig. 4h). In oblique sections, Halysis tubes appear ovoid and have varied lengths (arrows in Fig. 4i). When less-well preserved, as in the Upper Ordovician Lianglitage Formation of Bachu area in the Tarim Basin (e.g., Cai et al. 2008), Halysis tubes tend to become sparitic and, when severely affected by diagenesis, can appear as elliptical circles in cross sections, or be destroyed (Fig. 5).

\subsection{Microstructure of Halysis}

The tube wall of Halysis from the Middle Ordovician Laoshidan section in Northwest Ordos Basin exhibits fibronormal (laminofibrous) microstructure, i.e., it consists of parallel fibrous calcite perpendicular to the wall surface in both cross section (Fig. 6a-d) and longitudinal section (Fig. 6i-j). Under the scanning electron microscope, the tube wall is composed of thin lath-like calcite crystals with thickness of $1.2-2.5 \mu \mathrm{m}$, width of $5-10 \mu \mathrm{m}$ and length of $10-20 \mu \mathrm{m}$, arranged in a shingled pattern (Fig. 6e, f); and shows long flakes of calcite perpendicular to tube surface (Fig. 6k, l). The interior of the tube is filled with blocky calcite cement or micrite (Fig. 6g-l). 

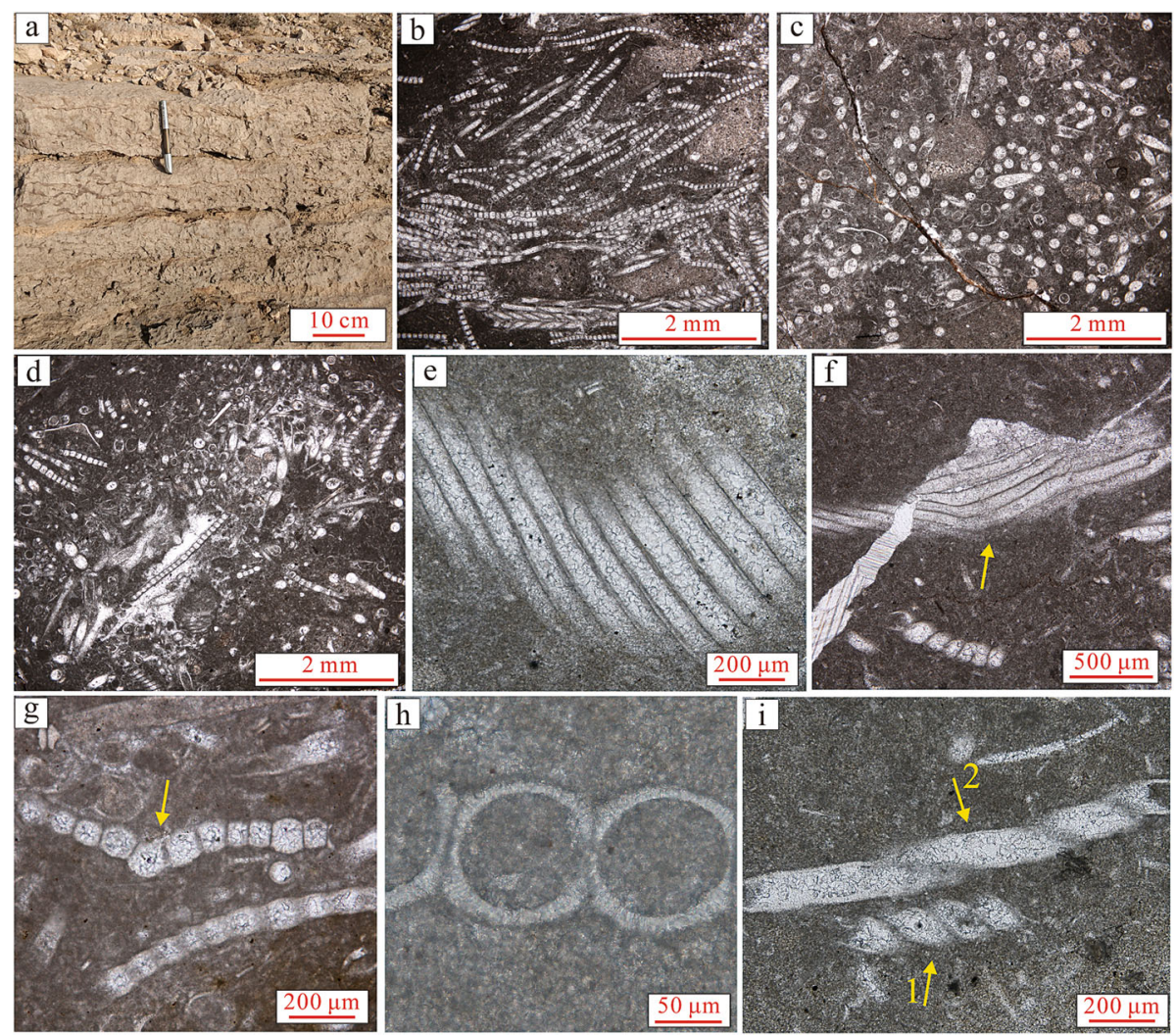

Fig. 4 Halysis from the Middle Ordovician Zhuozishan and Kelimoli Formations of the Laoshidan section in Northwest Ordos Basin, North China. a Outcrop of the thin- to medium-bedded limestone of the Zhuozishan Formation yielding Halysis; $\mathbf{b}$ Catenulate cross sections of abundant 'multiple-tube' Halysis; c Circular cross sections of abundant 'single-tube' Halysis; d 'Single-tube' Halysis and 'multiple-tube' Halysis unevenly scattered; e Longitudinal section of a 'multiple-tube' Halysis consisting of eleven tubes with each single tube about $500 \mu \mathrm{m}$ long; $\mathbf{f}$ Longitudinal section of a 'multiple-tube' Halysis resembling an undulated sheet (arrow); $\mathbf{g}$ Cross section of a 'multiple-tube' Halysis showing circles in various sizes and filled with sparite (arrow); $\mathbf{h}$ Cross section of a 'multiple-tube' Halysis showing the laminofibrous microstructure of tube walls composed of fibrous calcite perpendicular to wall surface and the micritic fillings in interiors of the tubes; i) Oblique sections of two 'multiple-tube' Halysis showing elongate cross sections of tubes (arrows 1 and 2)

Micrite fillings indicate that the tubes of Halysis were mostly open, since micrite cannot enter a closed tube. In contrast, the tube wall of Halysis from the Upper Ordovician Lianglitage Formation of the Tarim Basin exhibits inconspicuous laminofibrous microstructure (Fig. 5), due to recrystallization. Some tubes of Halysis show structures resembling the tabulae of tabulate corals (Fig. 6i, j) as very thin and slightly curved in the same direction. These tabula-like structures are not common in the studied samples, probably because they merged with cement.

The tubes of 'multiple-tube' Halysis are nearly circular in cross section in almost all cases, and appear chain-like in transverse section. The diameter of a Halysis tube measured parallel to the chain alignment (Dp) is approximately equal to the diameter measured normal to the chain alignment (Dn) (Fig. 7a). Mean values of Dp and Dn for the 'multiple-tube' Halysis are $110.6 \mu \mathrm{m}$ and $111.1 \mu \mathrm{m}$, and mean values of Dp and Dn for the 'single-tube' Halysis are $155.5 \mu \mathrm{m}$ and $157.5 \mu \mathrm{m}$ (Table 1), respectively. The wall thickness of a Halysis tube measured parallel to the chain alignment (Wp) and that measured normal (Wn) are also roughly equal (Fig. $7 \mathrm{~b}$ ). The mean Wp values of the 'multiple-tube' Halysis and the 'single-tube' Halysis are $9.8 \mu \mathrm{m}$ and $12.5 \mu \mathrm{m}$, which are nearly a tenth of their corresponding mean Dp values; the mean $\mathrm{Wn}$ values of the 'multiple-tube' Halysis and the 'single-tube' Halysis are $10.5 \mu \mathrm{m}$ and $12.7 \mu \mathrm{m}$ respectively, which are also nearly a tenth of their corresponding mean Dn values (Table 1; Fig. 7). The mean Dp, Dn, Wp, and Wn values of the 'single-tube' Halysis is respectively larger than those of the 'multiple-tube' Halysis, which illustrates that the size of the tube in 'single-tube' Halysis is basically larger than the mean size of the single tube in 'multiple-tube' Halysis (Table 1; Fig. 7). The Dp/Dn ratios of 'multiple-tube' Halysis range from 0.77 to 1.32 , and the variation of the Dp/Dn ratios of 'single-tube' Halysis is from 0.87 to 1.14; the $\mathrm{Wp} / \mathrm{Wn}$ ratios of 'multiple-tube' Halysis range from 0.50 to 1.33 and those of 'single-tube' Halysis vary from 0.77 to 1.29 (Table 1 ). 

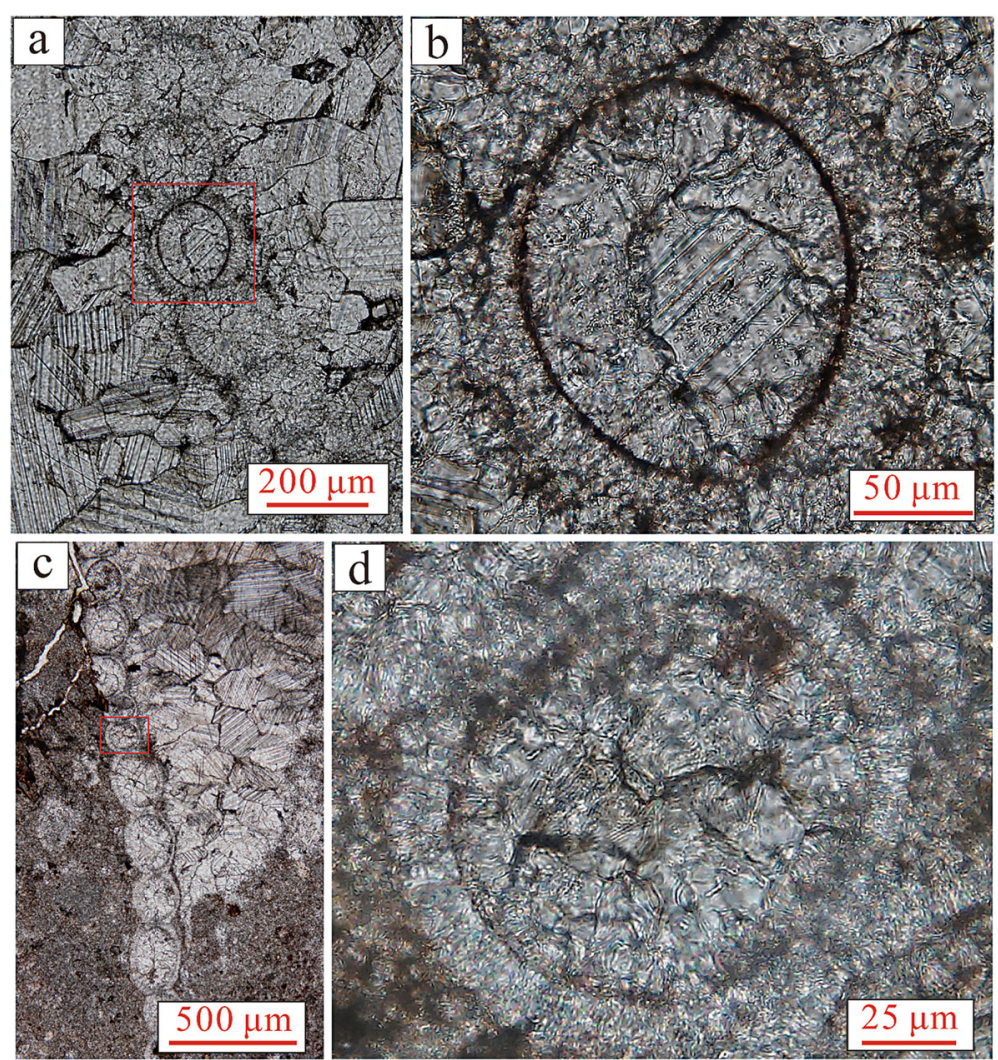

Fig. 5 Halysis from the Upper Ordovician Lianglitage Formation of Bachu area in the Tarim Basin, Northwest China. a Cross section of a 'multipletube' Halysis; b Enlarged view of the red box in Fig. 5 a shows an elliptical tube filled with sparite; c Cross section of a 'multiple-tube' Halysis composed of tubes with various diameters; $\mathbf{d}$ Enlarged view of the red box in Fig. 5c showing inconspicuous laminofibrous microstructure

The interiors of all tubes, far from the tube ends, are often, although not always, filled with granular calcite cement (Figs. 8, 9), while the tube ends are often filled by micrite. This could indicate that tabulae were present in all tubes before they merged with cement, which prevented the infilling of the interiors by micrite. And, since almost all Halysis skeletons were broken, the open ends of the tubes were filled by micrite. In Fig. 9c and e, the broken tubes are short and filled with micrite, without tabulae. In consideration of some previous observations also about the sediment filling of tubes (e.g., Frisch et al. 2013), this study could expect that if no tabula existed in the tubes, the interiors of some of these tubes would be filled with micrite.

\subsection{Tube reproduction}

'Multiple-tube' Halysis shows two modes of tube reproduction: fission and budding. Fission is the division of a mother tube into two daughter tubes by insertion of a microcrystalline wall in the center of the mother tube (Fig. 8a, b), and the two daughter tubes are parallel to each other and share a common wall. Budding is where a new branch begins from the contact between two adjacent tube walls. Initially, the new tube does not need too much space (Fig. 8c). As it grows, the space enlarges naturally and the daughter tube grows parallel to the old tubes (Fig. 8k). The first mode, i.e., fission, is more common (Fig. 8) during our observation. The diameters of the daughter tubes are smaller than that of the mother tube at the inception of fission (Fig. 8g-j). The relative frequency of budding, the number of budding sites versus the total tube number, may differ at different growth stages of the Halysis tube: in Fig. 8b, almost every tube has a new bud, while in Fig. 8k, budding occurs only locally in two out of fourteen tubes.

Reproduction in 'single-tube' Halysis is a process by which a mother tube develops into two daughter tubes, each with an independent wall, and the two new branches grow at an angle of $60^{\circ}-100^{\circ}$, with a Y-shaped configuration (Fig. 9). The difference between the diameters of the daughter tube and the mother tube is very small. Some of the individual branches have nearly the same diameter as the unbranched tube (Fig. 9a, b, f). The diameters of the tubes range from $112 \mu \mathrm{m}$ to $220 \mu \mathrm{m}$.

Based on observations on Halysis from the Middle Ordovician Laoshidan section in thin sections (Fig. 4) and their features of reproductions (Figs. 8 and 9), three types of morphologies are proposed for 'multiple-tube' 

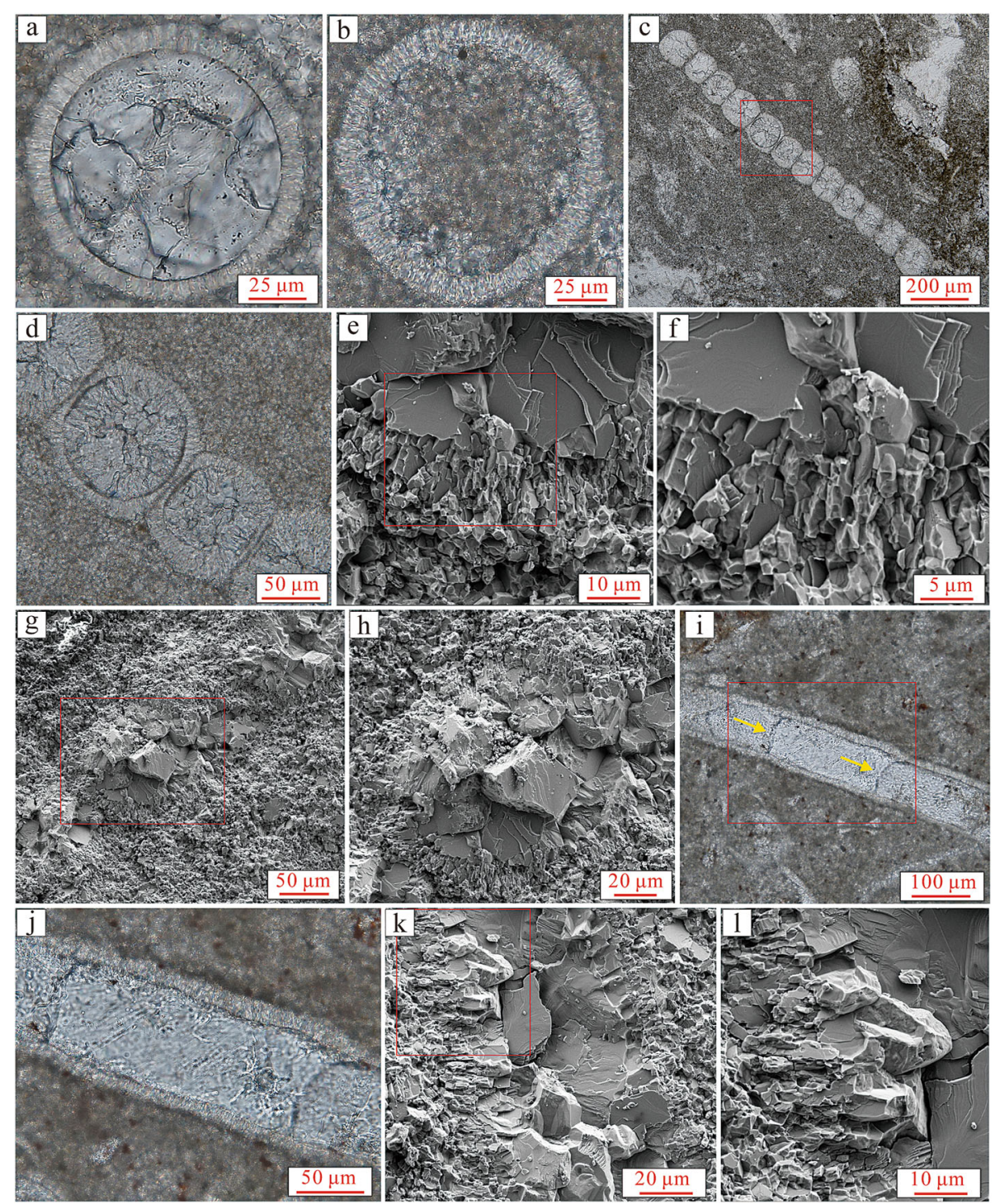

Fig. 6 Wall microstructure of Halysis from the Middle Ordovician Zhuozishan and Kelimoli Formations of the Laoshidan section in Northwest Ordos Basin, North China. a Cross section of a 'single-tube' Halysis shows the tube wall composed of fibrous calcite perpendicular to the tube surface, exhibiting laminofibrous microstructure, and the tube interior filled by blocky calcite; b Cross section of a 'single-tube' Halysis internally filled with micritic sediments, showing laminofibrous microstructure; c Cross section of a 'multiple-tube' Halysis composed of twelve tubes; $\mathbf{d}$ Partially enlarged view of the red box in Fig. $6 c$. Note the laminofibrous microstructure of the tube wall; e Detailed view of wall microstructure of a Halysis tube, composed of radially arranged lath-like calcite crystals perpendicular to the tube surface; $\mathbf{f}$ Partial enlarged view of the red box in Fig. 6e. Note thin lath-like calcite crystals arranged in a shingled pattern; $\mathbf{g}$ Cross section of a tube of 'multiple-tube' Halysis internally filled with blocky calcite; $\mathbf{h}$ Detailed view of the calcite in the red box in Fig. $6 \mathrm{~g}$; i Longitudinal section of a Halysis tube, with possible tabulae (pointed by yellow arrows); $\mathbf{j}$ Detailed view of the red box in Fig. 6i. Note the tube wall displaying laminofibrous microstructure; $\mathbf{k}$ Longitudinal section of a Halysis tube. Note that the internal filling is blocky calcite and the wall is composed of calcite flakes perpendicular to the tube surface; I Detailed view of the red box in Fig. 6k. a-d and $\mathbf{i}-\mathbf{j}$ are thin-section photomicrographs. $\mathbf{e}-\mathbf{h}$ and $\mathbf{k}-\mathbf{I}$ are scanning electron microscope images

Halysis. In the first type, which is the most common, partly-branching tubes are arranged parallelly (Fig. 10a). In the second and less common type, reproduction occurs as in the first type, with the only difference that the tubes curve at differing degrees (Fig. 10b). In the third and uncommon type, the new bud originates at the junction between two adjacent tube walls (Fig. 10c). And one morphology type for the 'single-tube' Halysis is that the tube bifurcates, forming two new branches at an angle of less than $100^{\circ}$ (Fig. 10d).

\subsection{Taxonomic position of Halysis in tabulate corals}

Construction and microstructure are two important features to distinguish skeletal fossils. Halysis consists of one tube or a series of tubes in chain-like arrangement (Shen and Neuweiler 2015) and exhibits laminofibrous 

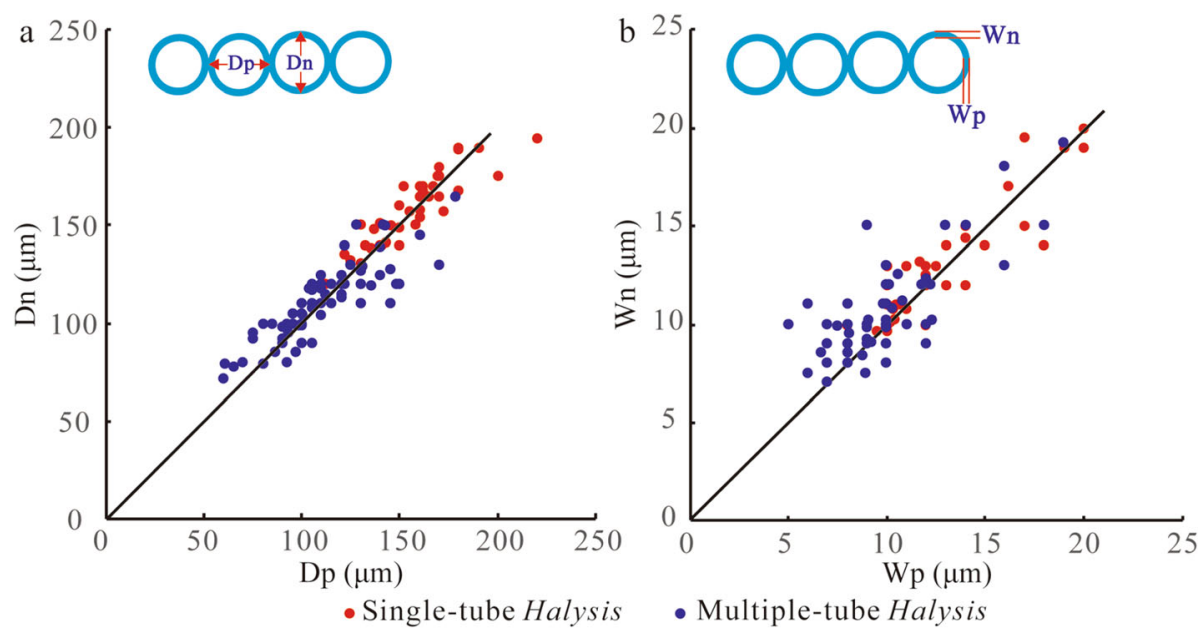

Fig. 7 The equivalence and the linear correlation for the Dp, Dn, Wp, and Wn values of the Halysis tube. Dp is the diameter of a Halysis tube measured parallel to the chain alignment, and Dn is the diameter of a Halysis tube measured normal to the chain alignment; Wp is the wall thickness of a Halysis tube measured parallel to the chain alignment, and $\mathrm{Wn}$ is the wall thickness of a Halysis tube measured normal to the chain alignment

(fibronormal) microstructure instead of micritic microstructure in the tube wall (e.g., Munnecke et al. 2001; Riding and Braga 2005; Feng et al. 2010) under planepolarized light. The laminofibrous or radiofibrous microstructure is common in the skeletons of Tabulata, rugose corals, stromatoporoids, Ostracoda and some other groups (Hill 1981; Dai 1994). Recognition of laminofibrous microstructure in Halysis suggests a possible affinity between Halysis and Tabulata.

The Tabulata is a large group of extinct Paleozoic corals characterized by skeletons composed of many tubes with developed or undeveloped tabulate structures. Tabulate corals can be classified into four morphological types: (1) those being reptant and composed of one to several trumpet-shaped tubes; (2) those being phacelloid in form and composed of many side-connected but contactless tubes; (3) those being massive and composed of many side-contact tubes; and, (4) those being dendroid and composed of contiguous tubes that are arranged parallelly like a fence (Hill 1981; Lin and Chi 1988). An Ordovician representative of fence-like tabulate corals is Catenipora (Fig. 11a), which is systematically assigned to Suborder Halysitina Sokolov 1947 (Hill 1981) and consists of numerous contiguous tubes parallel to each other.

'Multiple-tube' Halysis is similar to Catenipora in several aspects. Firstly, both are composed of paralleljuxtaposed tubes with a fence-like arrangement (Fig. 11). Secondly, tube walls in both have a laminofibrous microstructure, composed of fibrous calcite perpendicular or slightly oblique to the tube wall surface (Figs. 4, 6, 8 and 11). Third, Catenipora is characterized by the absence of septal spines (Wang and Deng 2010), and the same applies to Halysis. In addition, Halysis and Catenipora both occur in marlstone or dolomitic limestone (Fig. 2), which indicates that they both lived in a low energy environment. A possible difference is that Catenipora has distinct tabulae, but tabulae may have merged with cement in Halysis, though they were present in life (Figs. 8a-d, i-j, Fig. $10 \mathrm{~d}-$ e). Another difference is that the tubes in Catenipora are arranged into fence-like sheets that have a mesh-like

Table 1 Tube measurement of the Halysis from the Middle Ordovician Zhuozishan and Kelimoli Formations of the Laoshidan section in Northwest Ordos Basin, North China

\begin{tabular}{|c|c|c|c|c|c|c|}
\hline & $\mathrm{Dp}(\mu \mathrm{m})$ & $W p(\mu m)$ & Dn $(\mu \mathrm{m})$ & Wn $(\mu \mathrm{m})$ & $\mathrm{Dp} / \mathrm{Dn}$ & Wp/Wn \\
\hline \multicolumn{7}{|c|}{ ‘Multiple-tube' Halysis } \\
\hline Mean & 110.6 & 9.8 & 111.1 & 10.5 & 0.99 & 0.93 \\
\hline Maximun & 178 & 19 & 165 & 19.2 & 1.32 & 1.33 \\
\hline Minimum & 60 & 5 & 72 & 7 & 0.77 & 0.50 \\
\hline \multicolumn{7}{|c|}{ 'Single-tube' Halysis } \\
\hline Mean & 155.5 & 12.5 & 157.5 & 12.7 & 0.99 & 0.98 \\
\hline Maximun & 220 & 20 & 195 & 20 & 1.14 & 1.29 \\
\hline Minimum & 112 & 8 & 120 & 9.7 & 0.87 & 0.77 \\
\hline
\end{tabular}



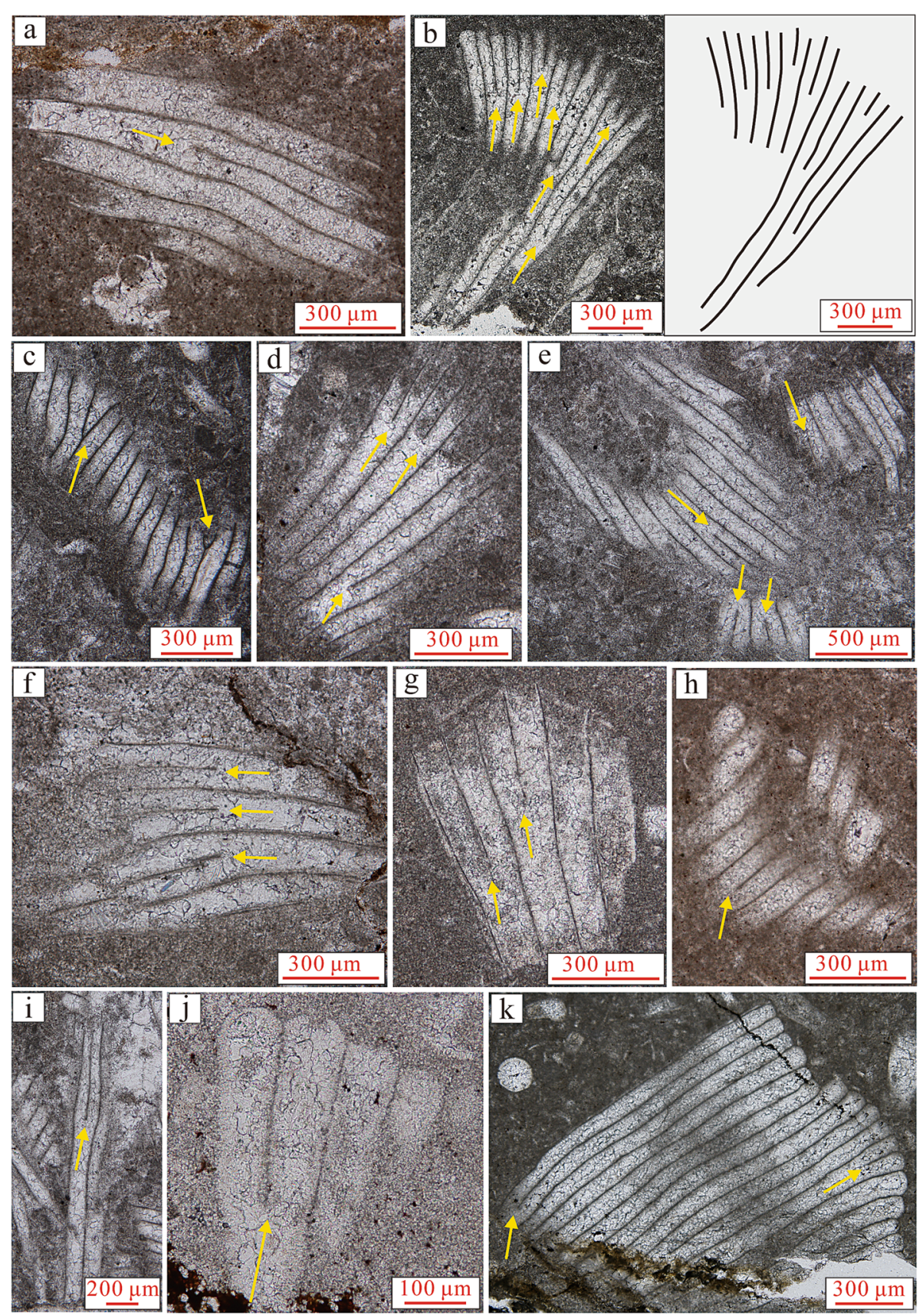

Fig. 8 Modes of reproduction in the 'multiple-tube' Halysis. a Longitudinal section of a 'multiple-tube' Halysis with fission increase; the arrow points to the new wall inserted in the center of the mother tube; $\mathbf{b}$ Longitudinal section of an erect colony; $\mathbf{c}$ Longitudinal section of a 'multipletube' Halysis with arrows pointing to the initial part of a new bud; $\mathbf{d}$ Longitudinal section of a 'multiple-tube' Halysis with arrows pointing to the fissions of different growth stages; e Longitudinal section of three 'multiple-tube' Halysis with arrows pointing to four new walls; $\mathbf{f}$ Longitudinal section of a 'multiple-tube' Halysis with arrows pointing to the fissions occurring at the same time. $\mathbf{g}$-j Longitudinal section of a 'multiple-tube' Halysis with arrows pointing to the fissions. Note the tube diameters of daughter tubes and of mother tubes; $\mathbf{k}$ Longitudinal section of a 'multiple-tube' Halysis shows the low frequency of budding (number of budding sites versus total tube number) along the growth direction

appearance in transverse section (Fig. 11b, c), but in Halysis the fence-like sheets do not appear to be mesh-like (Fig. 6). The third difference is that the tubes in Halysis are much smaller than those in Catenipora. Tube diameters of the 'multiple-tube' Halysis in this study range from
$60 \mu \mathrm{m}$ to $178 \mu \mathrm{m}$ (Table 1), and can reach $190-250 \mu \mathrm{m}$ in previous data (Riding and Braga 2005; Shen and Neuweiler 2015), whereas the tube diameters of Catenipora are much greater (Fig. 11d, e). Despite these three differences, overall similarities in their skeletal construction and tube wall 

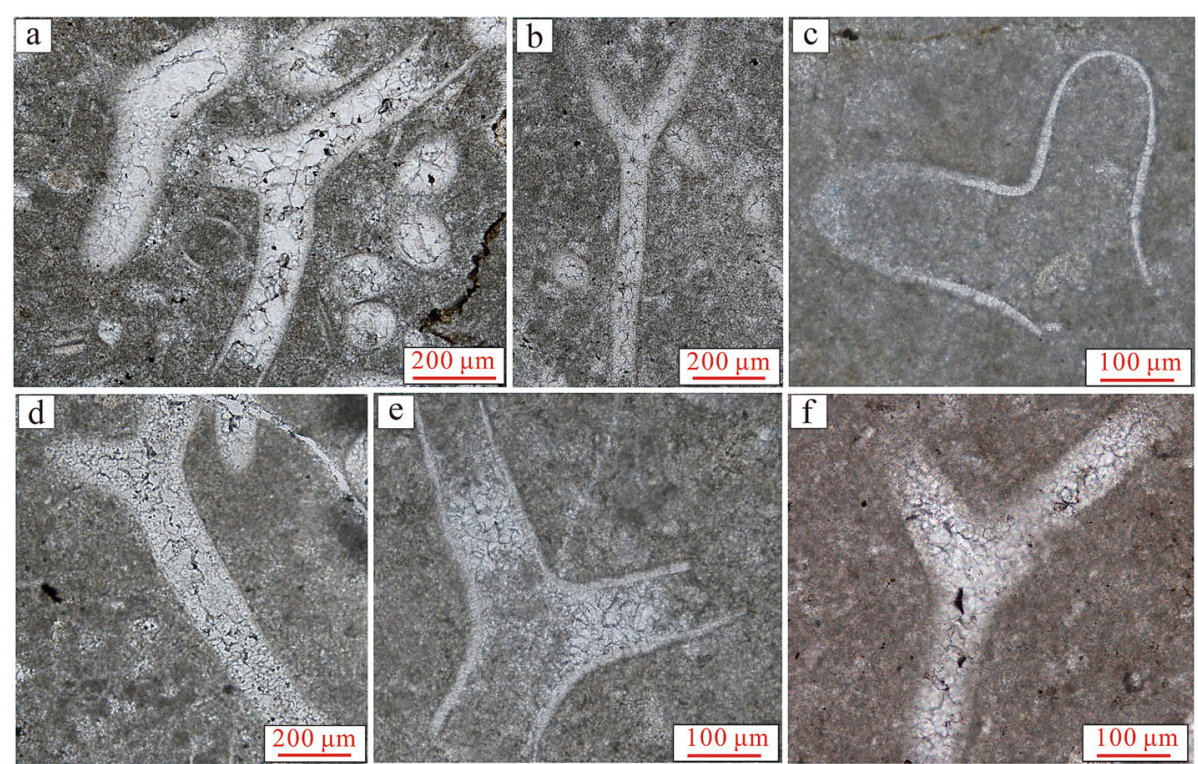

Fig. 9 Modes of reproduction in the 'single-tube' Halysis. a Longitudinal section of two 'single-tube' Halysis showing Y-shaped branching. Note that the daughter tubes have nearly the same diameter as the mother tube; $\mathbf{b}$ Two daughter tubes growing at an angle of about $60^{\circ}$ and having diameters similar to that of the mother tube; c Two daughter tubes growing at an angle of $90^{\circ}$ and showing their arc-shaped terminations; $\mathbf{d}$ The daughter tubes have been obscured by recrystallization, and probably are narrower than the mother tube; e The daughter tubes growing at an angle of about $100^{\circ}$ are a little narrower than the mother tube; $\mathbf{f}$ The diameters of the daughter tubes are almost the same as that of the mother tube

microstrcuture are obvious. Therefore, this study suggests that Halysis could have an affinity with Catenipora, and might also belong to the Tabulata.

The earliest occurrence of the 'multiple-tube' Halysis was in the Lower Ordovician (Guilbault et al. 1976), while the Catenipora-like corals did not appear until the Middle Ordovician (Hill 1981). Since Halysis is much older and smaller than Catenipora, we suggest that the 'multiple-tube' Halysis is a possible ancestor of the fence-like tabulate corals such as Catenipora.

Aulopora is a genus of the 'single-tube' type, composed of small trumpet-like tubes laterally connected at the base (Fig. 11f), and shows close similarities with the 'single-tube' Halysis. Tabulae may or may not be present in the Aulopora; where tabulae are present, they can be sparse or numerous (Fenton 1927; Hill 1981; Scrutton 1990). As noted above, tabulae can be present in the 'single-tube' Halysis but are not always observed (Fig. 6i$\mathrm{j}$ ), and in many cases, tabulae may have merged with cement. For example, the Halysis specimens in the Tarim Basin are severely affected by diagenesis and lack tabulae (Fig. 5). Nonetheless, more decisive aspects of our taxonomic assignment are based on the skeletal construction and tube microstructure of Halysis.

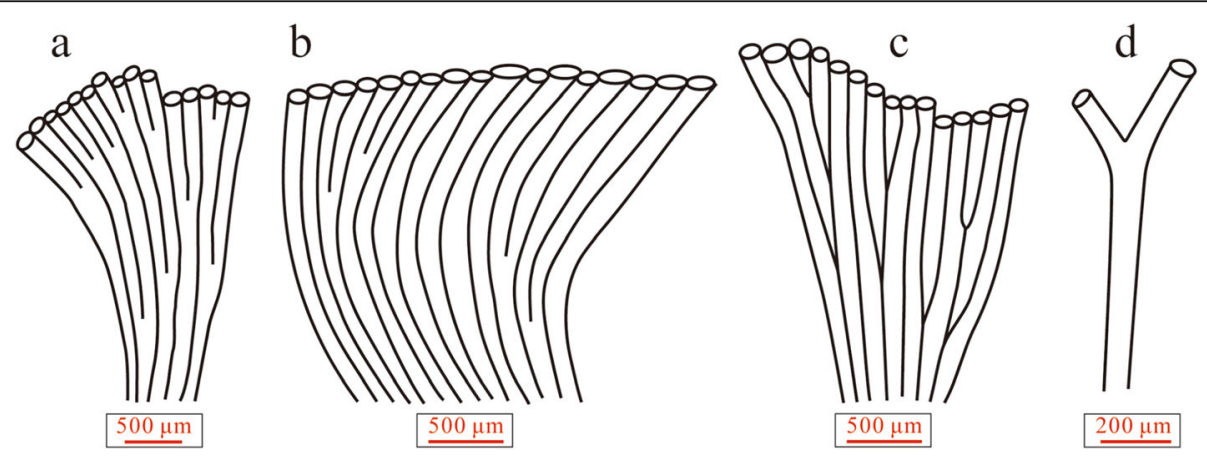

Fig. 10 Morphology of (a-c) the 'multiple-tube' Halysis reproduction and (d) the 'single-tube' Halysis reproduction. a Parallel-juxtaposed, partlybranching tubes, the most common type observed in the studied Laoshidan section; b Partly-branching tubes similar to $\mathbf{a}$ but curve at differing degrees; c Irregularly-curve side-contact tubes. Note that the new bud extruding from the contact between two adjacent tubes; $\mathbf{d}$ Bifurcation forming two new branches at an angle 

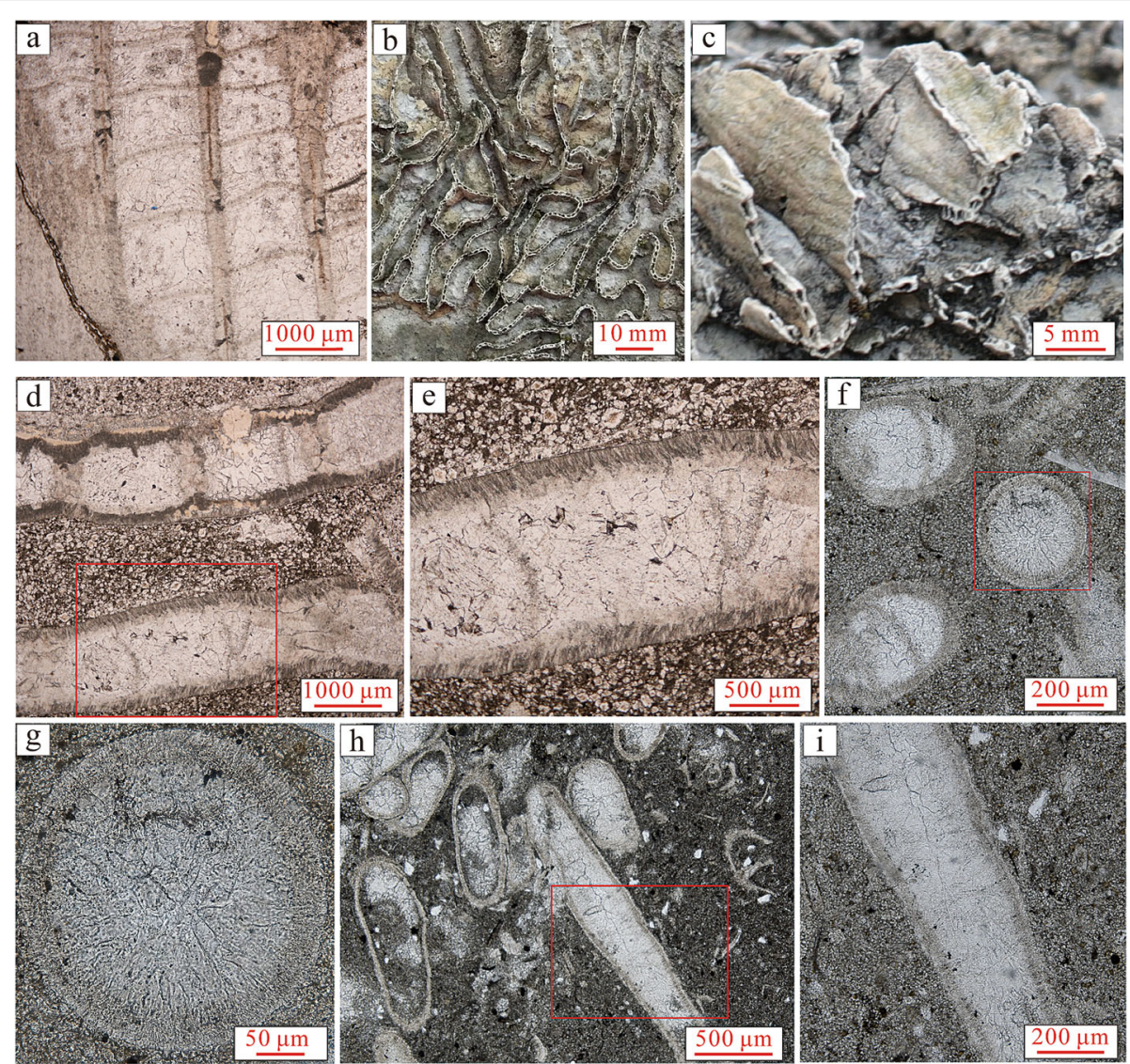

Fig. 11 Comparison between the tabulate corals Aulopora and Catenipora. a Longitudinal section of Catenipora, consisting of tubes with tabulae and fence-like arrangement; $\mathbf{b}$ Cross section of Catenipora; c Three-dimensional view of Catenipora, composed of tubes arranged in a fence forming mesh-like structure; $\mathbf{d}$ Longitudinal section of Catenipora, showing the laminofibrous microstructure of the tube walls composed of fiber calcite slightly oblique to tube surface; e Detailed view of the red box in Fig. 11d. Note the tube wall displaying laminofibrous microstructure; $\mathbf{f}$ One cross section and two oblique sections of Aulopora, displaying round and oval forms with diameters of 0.2-0.3 mm. The tube walls exhibit laminofibrous (fibronormal) microstructure and have average thickness of about $30 \mu \mathrm{m}$, with tabulae in the oblique sections; $\mathbf{g}$ Enlargement of the red box in Fig. 11f; $\mathbf{h}$ Longitudinal section of Aulopora; i) Enlargement of the red box in Fig. 11h. a-e were from the Upper Ordovician Sanqushan Formation in Yushan area, Jiangxi Province; $\mathbf{f - i}$ were from the Lower Devonian Sipai Formation of Xiangzhou area, Guangxi Province

The tubes of Aulopora and 'single-tube' Halysis are both round in cross sections and have thin walls with similar laminofibrous microstructure (Fig. 6a-b, Fig. 11 $\mathrm{f}$-g); and, they both exhibit elongate and somewhat quadrate or rectangular shapes (Fig. 6i-j, Fig. 11 h-i) in longitudinal sections. Even though there is a difference in the size ranges of these two genera, they have an overlap. The tube diameter of 'single-tube' Halysis in this study ranges from $112 \mu \mathrm{m}$ to $220 \mu \mathrm{m}$, and the tube diameter of Halysis described by Shen and Neuweiler (2015) can reach $247 \mu \mathrm{m}$; while tubes of Aulopora are $150-500 \mu \mathrm{m}$ in diameter (Fig. 12). Thus the tube-size ranges of Aulopora and Halysis show an overlap (Fig. 12). In addition, the tubes of Aulopora and 'single-tube' Halysis both show similar reproduction mode of mainly basal or lateral gemmation (Fenton and Fenton 1937), and of Y-shaped branching (Fig. 9), respectively. Both Aulopora and 'single-tube' Halysis first appear during the Early Ordovician Period. The above similarities also support the systematic position of Halysis in tabulate corals.

Halysis tubes are not closed and the opening for the polyps would be at the top (Fig. 10). The sections in Fig. $8 j$ and $k$ could be produced when the tubes were curved like in Fig. 10b. Whether the filling in the tubes is cement or sediment depends on how easily the sediment could enter the tubes. The tops and the ends of the Halysis tubes may be filled with sediment, whereas the interior may be filled with cement due to the presence of tabulae. Frisch et al. (2013) show some examples of tubes filled with sediment.

\section{Discussion}

Høeg (1932) placed Halysis in incertae sedis because he considered there was insufficient evidence to assign it to any family. Guilbault et al. (1976) attributed 


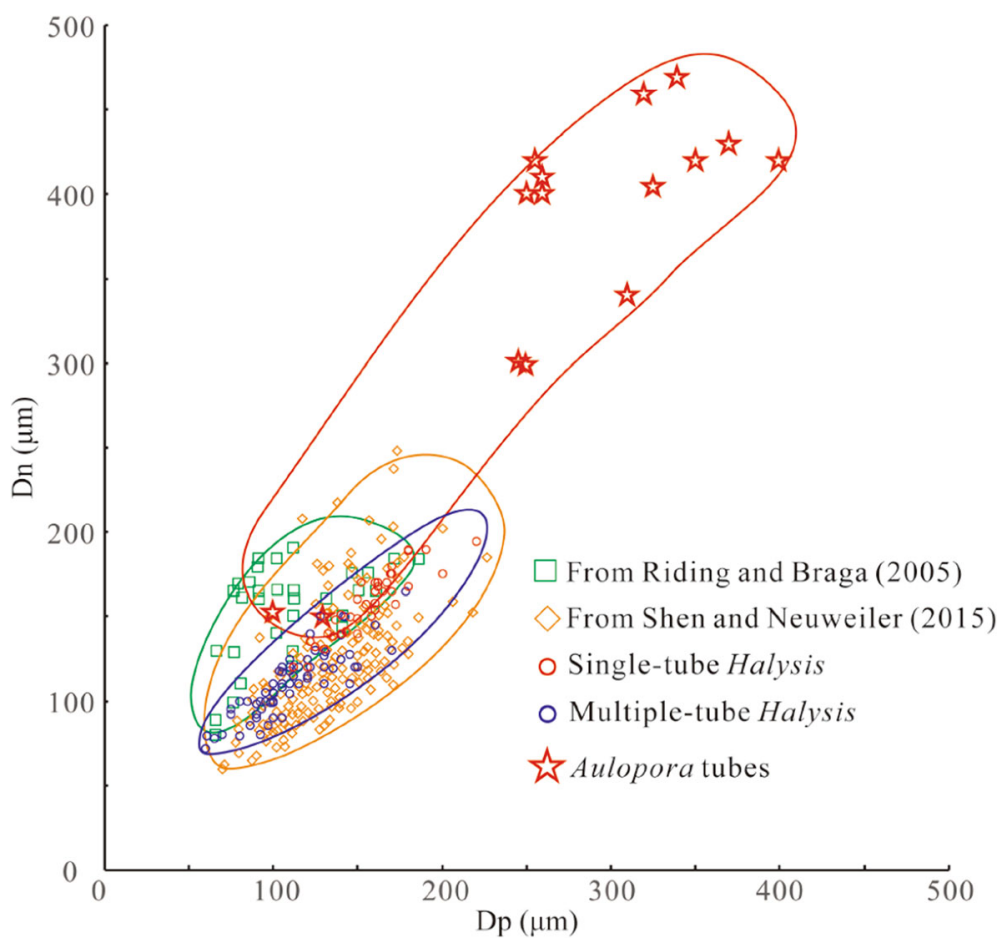

Fig. 12 Diameter-measurement comparisons of the Halysis tubes recorded in previous literature (Riding and Braga 2005; Shen and Neuweiler 2015) and studied in this study, together with the Aulopora. Tube diameters recorded as internal diameters in the literature (Munnecke et al. 2001; Frisch et al. 2013) are excluded

Halysis tentatively to the family Codiaceae in terms of the branching mode and the leaf-shaped morphology with a narrow stem fixed on the ground. Munnecke et al. (2001) considered that Halysis is a morphologically highly variable, palisade-like cyanobacterium. Riding and Braga (2005) concluded that the morphology of Halysis is more likely a single planar sheet of laterally adjoining cells and suggested that Halysis could be a coralline red alga. A three-dimensional model of Halysis revealed that the skeletons of Halysis consist of parallel-juxtaposed, partly-branching tubes, and the interpretation of a single sheet of adjoining cells was then rejected by Frisch et al. (2013).

A possible taxonomic affinity between Halysis and siphonous green algae was proposed by Shen and Neuweiler (2015). Controversy about the taxonomic affinity of Halysis continues and we therefore consider comparisons between Halysis and calcareous green algae, calcareous red algae and cyanobacteria based on their microstructure, tube size and reproduction mode.

Benthic fossil calcareous green algae include two main groups, the Dasycladales (Fig. 13a-b) and the Bryopsidales (siphonales) (Fig. 13c-d). Udoteaceae and Codiaceae are two families of the order Bryopsidales (Verbruggen et al. 2009). Calcification in living Udoteaceae is characterized by precipitation of needle-shaped aragonite, a process described as "early micritization" by Macintyre and Reid (1995). Since aragonite is not a stable mineral, it generally transforms to granular calcite in diagenesis, and is preserved as granular calcite in fossils (Mu 1991; Granier 2012). All fossils of Codiaceae are composed of granular calcite. A similar example, based on our own materials, is the Gymnocodiacean Permocalculus sp. from the Middle Permian Lengwu Fomation of Tonglu area in Zhejiang Province, East China (Fig. 13cd). The differences between Halysis and Codiaceae include: (1) Halysis consists of small tubes and Codiaceae are composed of filaments. Though tubes and filaments are roughly similar in shape, the former are more regular and generally straight, while the latter generally are irregularly curved. (2) The tubes in Halysis are parallel, but the filaments in Codiaceae and Udoteaceae are generally irregularly intertwined in bundles. (3) The tubes in Halysis have regular calcareous walls, while the filaments of Codiaceae have not. The tube wall of Halysis has a laminofibrous microstructure, whereas the skeletons in Codiaceae are composed of granular calcite. And, the spaces between filaments are lined by the carbonate precipitate induced by metabolism of the living Codiaceae, which is originally needle-like but changes to granular calcite during diagenesis. In addition, the elements of Udoteaceae are much larger than Halysis. Because of these differences, the likelihood that Halysis belongs to 

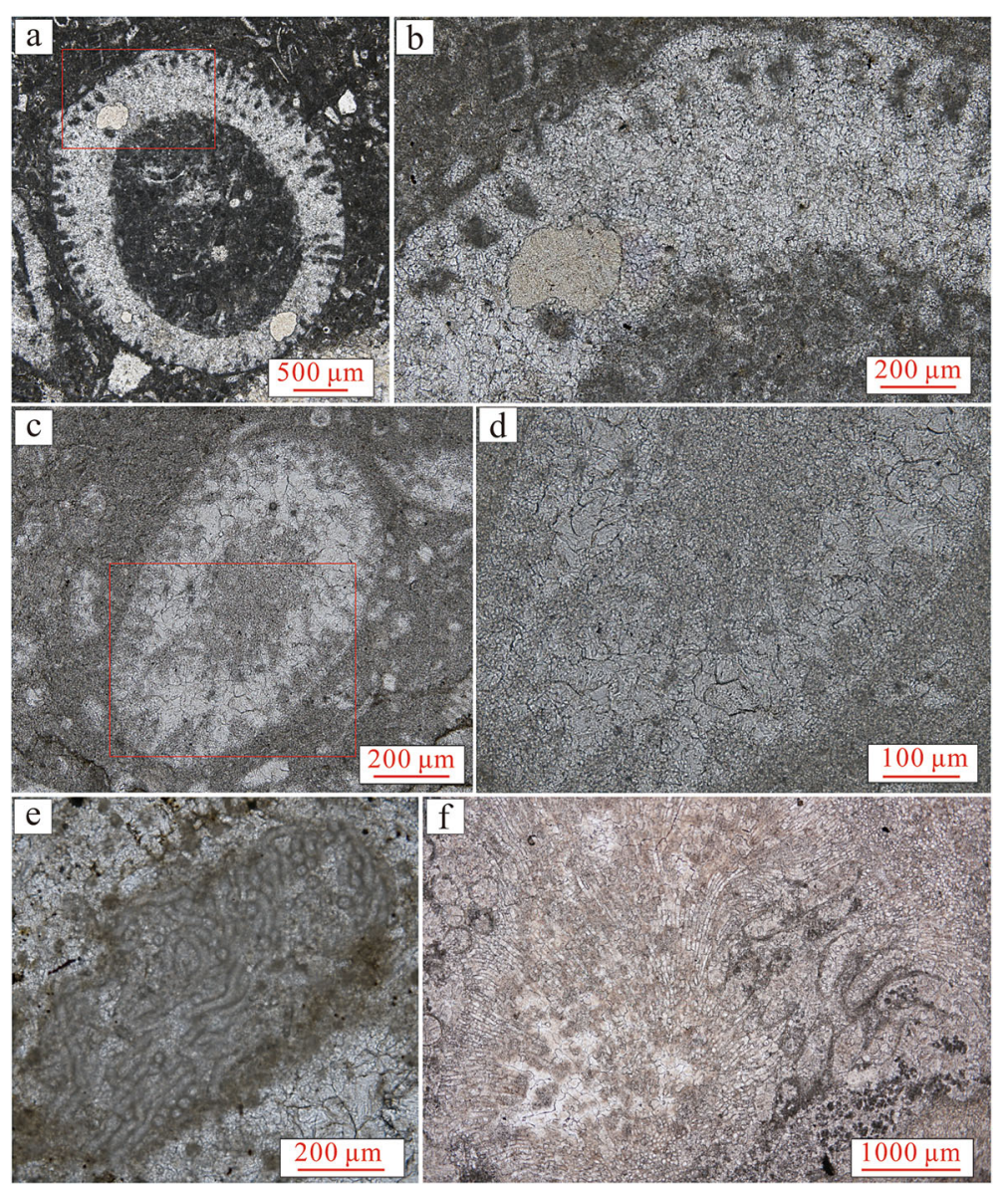

Fig. 13 Comparisons between calcareous algae and cyanobacteria. a-b Dasycladales, whose calcareous skeletons were composed of granular calcite, from the Upper Ordovician of Shijiezigou area in the Ordos Basin, Ningxia, Northwest China; c-d Gymnocodiacean Permocalculus sp., a common Permian Codiaceae green alga of the Bryopsidales, with a calcareous skeleton composed of granular calcite, from the Middle Permian Lengwu Formation of the Lengwu section in Tonglu County, Zhejiang Province, East China; e Girvanella, a representative of the filamentous calcified cyanobacteria, possesses unbranched filaments with thin micritic walls, from the Middle Ordovician of the Qianlishan section in the northwestern Ordos Basin; f A mushroom-like skeleton of Pseudosolenopora filiformis (Nicholson 1888), composed of calcified cell trichomes in radiate arrangement, with calcified cell walls composed of micrites, from the Upper Ordovician of Well 822 in the Tarim Basin, Xinjiang, Northwest China (Yang et al. 2015)

Codiaceae and/or Udoteaceae (Bryopsidales; siphonales) is minimal.

Distinct difference also exists between calcified cyanobacteria and Halysis. Cyanobacteria include filamentous types and non-filamentous types. Only some genera have calcified fossils. The non-filamentous calcified cyanobacteria have no morphological similarity with the Halysis. The filamentous sheaths of filamentous calcified cyanobacteria can be preserved as tubes (Riding 1977, 2011; Liu et al. 2011). However, the filaments of cyanobacteria are irregularly curved (e.g., Girvanella) (Riding 1991) while the tubes in Halysis are generally straight. All tubes in Halysis are parallel to each other and arranged like a fence, and possess the laminofibrous microstructure; whereas filaments in the filamentous calcified cyanobacteria are composed of micrites (Pratt 2001; Liu and Zhang 2012) (Fig. 13e). The size difference between the filaments of calcified cyanobacteria and the tubes of Halysis is conspicuous. The diameter of the filaments is generally very small and cannot exceed $50 \mu \mathrm{m}$, but the diameter of many known Halysis tubes can exceed $150 \mu \mathrm{m}$ (Fig. 12). The commonest mode of reproduction in the cyanobacteria is vegetative and asexual, either by means of binary or multiple fission in unicellular and colonial forms or by fragmentation and spore formation in filamentous species (Gualtieri and Barsanti 2014), while the reproduction in Halysis is budding and branching. Considering these differences, the taxonomic similarity of Halysis with calcified cyanobacteria proposed by Munnecke et al. (2001) is not confirmed.

Halysis differs from calcified red algae. Red algae constitute a very large group, only a few of which have calcified skeletons. The calcified thallus of the genus Pseudosolenopora 
filiformis (Nicholson 1888) (Fig. 13f) found from the Upper Ordovician in the Tarim Basin (Yang et al. 2015), is composed of radially-arranged calcified cells with widths of $22-50 \mu \mathrm{m}$. The cell walls in radiate direction are calcified better than the concentric walls, and are more distinct. Coralline red algae have two forms: articulate and non-articulate; the former form includes more than ten genera; the latter also called crustose coralline algae (CCA) includes more than twenty genera. The thalli of the articulate forms are composed of radiallyarranged calcified cells. The thalli of the non-articulate forms consist of two parts, a basal part composed of radiallyarranged calcified cells and a surface part composed of several layers of grid-like calcified cells. The thalli of most Corallinaceae genera (one of the extant Coralline families of red algae) are composed of laterally-connected cell filaments, and, one of the genera, Lithoporella, has a thallus composed of a unistratose hypothallium and a unistratose epithelium (Turner and Woelkerling 1982a; Liu 1990). At first sight, the vertical sections of Lithoporella and Lithophyllum shown by Riding and Braga (2005, their figure 3) were somewhat similar to the cross section of Halysis, and this is probably why an affinity between Halysis and Corallinaceae was proposed. However, there are substantial differences between them. The most important is that Halysis consists of tubes arranged in a fence-like layer, while the thalli in the calcified red algae are composed of radially-arranged cells (Fig. 13f). Another important difference is that the tube walls of Halysis have a laminofibrous microstructure (Fig. 6a-b), while the calcified cell walls in Corallinaceae have two Mg-calcite layers or aragonitic crystals (Basso 2012; Caragnano et al. 2014) which can turn into micrite or granular calcite during diagenesis. Most corallines are dioecious, and the reproduction of coralline red algae is mainly completed by the fertilization of female conceptacles and the vegetative propagation, during which a fragmentary thallus grows into a new coralline (Fott 1971). Lithoporella has gametic conceptacle or carposporophyte and cannot rely on vegetative propagation (Turner and Woelkerling 1982b). This feature is significantly different from that of Halysis. Due to these considerable differences, the affinity between Halysis and the coralline red algae was rejected by Frisch et al. (2013) and Shen and Neuweiler (2015). In this study, we agree that the Halysis differs from coralline red algae in morphology, skeletal microstructure and reproduction mode.

\section{Conclusions}

1) Halysis Høeg 1932 is a calcareous microfossil that is common in the Middle Ordovician Darriwilian Stage of the northwestern Ordos Basin, North China, and mainly shows two types of skeletal construction of the 'multiple-tube' and the 'single-tube'.

2) The 'multiple-tube' Halysis is more common, and is reproduced by fission and budding; and, the 'single-tube' Halysis is reproduced by Y-shaped branching. The tube wall has a laminofibrous microstructure, described for the first time in this study.

3) Halysis differs from calcified cyanobacteria, calcareous green and red algae in skeletal construction and microstructure. In contrast, Halysis resembles tabulate corals, such as Catenipora and Aulopora, in their skeletal construction and microstructure. Thus, the affinity between Halysis and calcified cyanobacteria, and the affinity between Halysis and calcareous green and red algae, proposed by previous researchers are not supported by this study. Furthermore, the similarities both between 'multiple-tube' Halysis and Catenipora, and between 'single-tube' Halysis and Aulopora, support the taxonomy of Halysis in tabulate corals, as a possible ancestor of the group.

\section{Abbreviations}

Dp: The diameter of a Halysis tube measured parallel to the chain alignment; Dn: The diameter of a Halysis tube measured normal to the chain alignment; Wp: The wall thickness of a Halysis tube measured parallel to the chain alignment; Wn: The wall thickness of a Halysis tube measured normal to the chain alignment

\section{Acknowledgements}

The authors sincerely thank Prof. Robert Riding for his kindly help on checking the original manuscript.

\section{Authors' contributions}

LIZ and YSW participated in the field work, conceived the idea of the study and wrote the manuscript. HXJ and HPB interpreted the results and revised the manuscript. YYZ participated in the field work and revised the manuscript. JFR and ZLH discussed the results and revised the manuscript. The authors read and approved the final paper.

\section{Funding}

This work was financially supported by the National Science and Technology Major Project (Grant Nos. 2016ZX05004-006 and 2016ZX05004-004), the Strategic Priority Research Program (B) of the Chinese Academy of Sciences (Grant No. XDB26000000), and the National Natural Science Foundation of China (Grant Nos. 41502004 and 41902110).

\section{Availability of data and materials}

All data generated or analyzed during this study are included in this published paper.

\section{Competing interests}

The authors declare that they have no competing interests.

\section{Author details}

'Key Laboratory of Cenozoic Geology and Environment, Institute of Geology and Geophysics, Chinese Academy of Sciences, Beijing 100029, China. ${ }^{2}$ Innovation Academy for Earth Science, Chinese Academy of Sciences, Beijing 100029, China. ${ }^{3}$ China United Coalbed Methane Corporation, LTD, Beijing 100011, China. ${ }^{4}$ Institute of Paleontology, Hebei Geo University, Shijiazhuang 050031, Hebei Province, China. ${ }^{5}$ University of Chinese Academy of Sciences, Beijing 100049, China. ${ }^{6}$ Research Institute of Petroleum Exploration and Development, Changqing Oilfield, Xi'an 710021, Shaanxi Province, China.

Received: 27 September 2019 Accepted: 19 August 2020

Published online: 25 September 2020

\section{References}

Basso, D. 2012. Carbonate production by calcareous red algae and global change. Geodiversitas 34: 13-33.

Cai, X.Y., Y.S. Wu, H.X. Jiang, and J.B. Zou. 2008. Paleoecology of MiddleUpper Ordovician reefal community in Bachu, Xinjiang, northwestern 
China. Acta Microbiologica Sinica 82: 1046-1052 (in Chinese with English abstract).

Caragnano, A., D. Basso, D.E. Jacob, D. Storz, G. Rodondi, F. Benzoni, and E. Dutrieux. 2014. The coralline red alga Lithophyllum kotschyanum $\mathrm{f}$. affine as proxy of climate variability in the Yemen coast, Gulf of Aden (NW Indian Ocean). Geochimica et Cosmochimica Acta 124: 1-17.

Dai, Y. 1994. Biomineralogy, 572. Beijing: Petroleum Industry Press (in Chinese).

Feng, Q., Y.M. Gong, and R. Riding. 2010. Mid-late Devonian calcified marine algae and cyanobacteria, South China. Journal of Paleontology 84: 569-587.

Fenton, M.A. 1927. New species of Aulopora from the Devonian of lowa. American Midland Naturalist 10: 373-384.

Fenton, M.A., and C.L. Fenton. 1937. Aulopora: A form-genus of tabulate corals and bryozoans. American Midland Naturalist 18: 109-115.

Fott, B. 1971. Algenkunde. 2nd ed, 581. Jena: VEB Gustav Fischer Verlag.

Frisch, K., A. Munnecke, C. Schulbert, and Y. Zhang. 2013. Tubes or cell sheet? A 3-D reconstruction of Halysis Høeg, 1932, from the upper Ordovician of South China. Facies 59: 113-132.

Granier, B. 2012. The contribution of calcareous green algae to the production of limestones: A review. Geodiversitas 34: 35-60.

Gualtieri, P., and L. Barsanti. 2014. Algae: Anatomy, biochemistry, and biotechnology. 2nd ed, 325 pp. Boca Raton: CRC Press.

Guilbault, J.P., C. Hubert, and B.L. Mamet. 1976. Nuia et Halysis, deux algues ordoviciennes énigmatiques des basses-Terres du Saint-Laurent. Le Naturaliste Canadien 103: 119-132

Hill, D. 1981. Rugosa and Tabulata. In Treatise on invertebrate paleontology, part F, Coelenterata, supplement 1, ed. C. Teichert, 762 pp. Boulder, Colorado and Lawrence, Kansas: The Geological Society of America and The University of Kansas.

Høeg, O.A. 1932. Ordovician algae from the Trondheim area. In The Hovin Group in the Trondheim Area, II, paleontological partSkr utgift Nor Vidensk Akad Oslo Matem-Naturv Kl, ed. J. Kiær, vol. 1927, 63-96.

Jing, X., H. Zhou, and X. Wang. 2015. Ordovician (middle Darriwilian-earliest Sandbian) conodonts from the Wuhai area of Inner Mongolia, North China. Journal of Paleontology 89: 768-790.

Lin, B.Y., and Y.Y. Chi. 1988. Tabulatomorpha, 467 pp. Beijing: Geological Publishing House.

Liu, L., Z. Yang, and Y. Wu. 2011. Calcified cyanobacteria from the Upper Ordovician Lianglitage formation, Central Tarim Basin, Xinjiang. Acta Palaeontologica Sinica 50: 492-510 (in Chinese with English abstract).

Liu, W., and X. Zhang. 2012. Girvanella-coated grains from Cambrian oolitic limestone. Facies 58: 779-787.

Liu, Z.L. 1990. Introduction to fossil algae, 491 pp. Beijing: Advanced Education Press.

Macintyre, I.G., and R.P. Reid. 1995. Crystal alteration in a living calcareous alga (Halimeda): Implications for studies in skeletal diagenesis. Journal of Sedimentary Research 65: 143-153.

Mamet, B., and H. Shalaby. 1995. Algues benthiques ordoviciennes de la plateforme du Saint-Laurent. Revue de Micropaleontologie 38: 229-244.

Mu, X. 1991. Fossil Udoteaceae and Gymnocodiaceae. In Calcareous algae and stromatolites, ed. R. Riding, 146-166. Berlin: Springer-Verlag.

Munnecke, A., C. Samtleben, T. Servais, and D. Vachard. 1999. Semobservation of calcareousmicro- and nano-fossils incertae sedis from the Silurian of Gotland, Sweden: Preliminary results. Geobios 32: 307-314.

Munnecke, A., T. Servais, and D. Vachard. 2001. Halysis Høeg, 1932 - A problematic Cyanophyceae: New evidence from the Silurian of Gotland (Sweden). Neues Jahrbuch für Geologie und Paläontologie (Monatsheft) 2001 (1): 21-42

Nicholson, H.A. 1888. On certain anomalous organisms which are concerned in the formation of some of the Palàeozoic limestones. Geological Magazine 25: 15-24.

Poncet, J. 1986. Les algues calcaires du Paléozöıques inférieur de la Bai d'Hudson et de l'Archipel arctique canadien. Bulletin du Centre de recherches Exploration Production Elf-Aquitaine 10: 259-282.

Pratt, B.R. 2001. Calcification of cyanobacterial filaments: Girvanella and the origin of lower Paleozoic lime mud. Geology 29: 763-766.
Riding, R. 1977. Calcified Plectonema (blue-green algae), a recent example of Girvanella from Aldabra atoll. Palaeontology 20: 33-46.

Riding, R. 1991. Calcified cyanobacteria. In Calcareous algae and stromatolites, ed. R. Riding, 55-87. Berlin: Springer-Verlag.

Riding, R. 2011. Microbialites, stromatolites, and thrombolites. In Encyclopedia of Geobiology, Encyclopedia of earth science series, ed. J. Reitner and V. Thiel, 635-654. Heidelberg: Springer.

Riding, R., and J.C. Braga. 2005. Halysis Høeg, 1932 - An Ordovician coralline red alga? Journal of Paleontology 79: 835-841.

Scrutton, C.T. 1990. Ontogeny and astogeny in Aulopora and its significance, illustrated by a new non-encrusting species from the Devonian of Southwest England. Lethaia 23: 61-75.

Shen, Y., and F. Neuweiler. 2015. Halysis Høeg, 1932 in Ordovician carbonate mounds, Tarim Basin, NW China. Palaios 30: 692-706.

Sokolov, B.S. 1947. Novye Tabulata ordovika Grenlandii. Akademii Nauk SSSR 58 (3): 469-472.

Stouge, S. 1984. Conodonts of the Micldle Ordovician table head formation, Western Newfoundland. In Fossils and strata, 16, 145 pp. Oslo: Universitetsforlaget.

Stouge, S. 2012. Middle Ordovician (late Dapingian-Darriwilian) conodonts from the cow head group and lower head formation, western Newfoundland, Canada. Canadian Journal of Earth Sciences 49: 59-90.

Stouge, S., P.D. Du, and Z.X. Zhao. 2011. Middle Ordovician (Darriwilian) global conodont zonation based on the Dawangou and Saergan formations of the western Tarim region, Xinjiang Province, China. In Ordovician of the world Cuadernos Del Museo Geominero. Volume 14, ed. J.C. Gutiérrez-Marco, I. Rábano, and D. Garcia-Bellido, 581-586. Madrid: Instituto Geológico y Minero de España.

Turner, J.A., and W.J. Woelkerling. 1982a. Studies on the MastophoraLithoporella complex (Corallinaceae, Rhodophyta) I. meristems and thallus structure and development. Phycologia 21: 201-217.

Turner, J.A., and W.J. Woelkerling. 1982b. Studies on the MastophoraLithoporella complex (Corallinaceae, Rhodophyta). II. Reproduction and generic concepts. Phycologia 21: 218-235.

Verbruggen, H., M. Ashworth, S.T. Loduca, C. Vlaeminck, E. Cocquyt, T. Sauvage, F.W. Zechman, D.S. Littler, M.M. Littler, and F. Leliaert. 2009. A multi-locus time-calibrated phylogeny of the siphonous green algae. Molecular Phylogenetics and Evolution 50: 642-653.

Wang, G.X., and Z.Q. Deng. 2010. Application of cluster analysis to classification of Cateniporids. Acta Palaeontologica Sinica 49: 478-486 (in Chinese with English abstract).

Wang, Z., H. Zhou, X. Wang, X. Jing, Y. Zhang, L. Yuan, and Z. Shen. 2016. The Ordovician basin prototype in the Northwest Ordos Basin - Constraint from the Ordovician sedimentary respond in the Helan-Zhuozi Mountains. Geological Review 62: 1041-1061 (in Chinese with English abstract).

Wang, Z.H., S.M. Bergstom, Y.Y. Zhen, X. Chen, and Y.D. Zhang. 2013. On the integration of Ordovician conodont and graptolite biostratigraphy - New examples from Gansu and Inner Mongolia in China. Alcheringa 37: 510-528.

Yang, H.J., Y.S. Wu, Z.Y. Xiao, Z.B. Huang, H.X. Jiang, W.Q. Pan, L.J. Liu, Z.L. Yang, and X.L. Chang. 2015. Cyanobacteria, algae, bryozoan, coral, and Stromatoporoid fossils from Ordovician of Tarim Basin, 201. Beijing: Geological Publishing House (in Chinese).

Zheng, L., H. Bao, Y. Wu, L. Sun, H. Jiang, J. Ren, Z. Huang, and L. Liu. 2018. Distinguishing coral reef facies from coral-bearing open platform facies: Examples from Ordovician Ordos Basin, Northwest China. Palaeogeography, Palaeoclimatology, Palaeoecology 495: 72-86.

Zhu, R.X., J.H. Yang, and F.Y. Wu. 2012. Timing of destruction of the North China Craton. Lithos 149: 51-60.

\section{Publisher's Note}

Springer Nature remains neutral with regard to jurisdictional claims in published maps and institutional affiliations. 